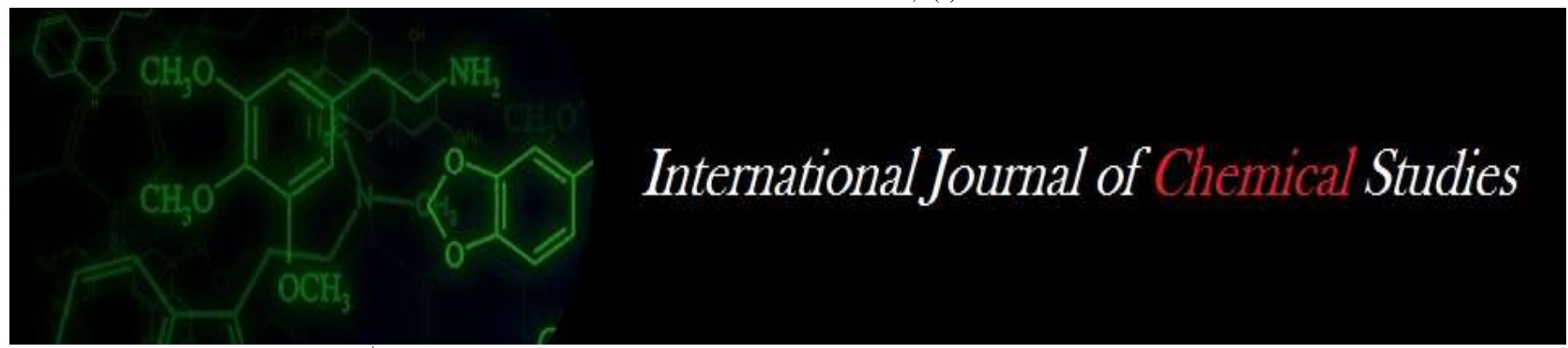

P-ISSN: 2349-8528

E-ISSN: 2321-4902

www.chemijournal.com

IJCS 2020; 8(6): 1617-1621

(C) 2020 IJCS

Received: 03-10-2020

Accepted: 09-11-2020

\section{Ambhore SS}

Department of Animal

Husbandry and Dairy Science,

Vasantrao Naik Marathwada

Krishi Vidyapeeth, Parbhani,

Maharastra, India

\section{PV Padghan}

Department of Animal

Husbandry and Dairy Science,

Vasantrao Naik Marathwada

Krishi Vidyapeeth, Parbhani,

Maharastra, India

GK Londhe

Department of Animal

Husbandry and Dairy Science,

Vasantrao Naik Marathwada

Krishi Vidyapeeth, Parbhani,

Maharastra, India

Soni Khobragade

Department of Animal

Husbandry and Dairy Science,

Vasantrao Naik Marathwada

Krishi Vidyapeeth, Parbhani,

Maharastra, India
Corresponding Author: Ambhore SS

Department of Animal

Husbandry and Dairy Science,

Vasantrao Naik Marathwada

Krishi Vidyapeeth, Parbhani,

Maharastra, India

\section{Studies on physico-chemical properties of buffalo milk ghee prepared by using turmeric powder (Curcuma longa $\mathbf{L}$.}

\author{
Ambhore SS, PV Padghan, GK Londhe and Soni Khobragade
}

DOI: https://doi.org/10.22271/chemi.2020.v8.i6w.10996

\begin{abstract}
In the present investigation ghee was prepared by considering treatment combination of buffalo milk and turmeric powder as $99.5 \%, 99 \%$ and $98.5 \%$ of buffalo milk and $0.5 \%, 1 \%$ and $1.5 \%$ of turmeric powder. The physico-chemical parameters include moisture, free fatty acid, iodine value, peroxide value, melting point, butyro-refractoeter reading were studied. It was observed that as the turmeric powder increase decrease in moisture content, peroxide value, butyro-refractometer reading, free fatty acid of the developed product.
\end{abstract}

Keywords: Buffalo milk, Ghee, Turmeric powder, physico-chemical properties

\section{Introduction}

Plants have been used since ancient times to cure diseases and improve human health (Taher et al. 2017) ${ }^{[32]}$. Herbs and spices come from different parts of the plant are used to impart an aroma and taste to food. Several herbs have therapeutic properties such as antioxidative, antiinflammatory, antidibtic, anti-hypertensive and anti-microbial activities (Samah and Youssef 2019) [26]. Consumption of herbs has significant health promoting effect and reduces the incidence of cardiovascular disease, cancer and various degenerative diseases (Singh et al. 2006; Craig 1999; Shishodia et al. 2005) ${ }^{[29,6,28]}$. Turmeric has also been used for centuries in Ayurvedic medicine, which integrates the medicinal properties of herbs with food. One tablespoon of turmeric powder contains: 29 calories, $2.1 \mathrm{~g}$ of fiber, $0.91 \mathrm{~g}$ of protein, $0.31 \mathrm{~g}$ of fat, $0.3 \mathrm{~g}$ of sugar, $6.31 \mathrm{~g}$ of carbohydrates, $26 \%$ manganese, $3 \%$ Vitamin C, $16 \%$ iron, $5 \%$ potassium, $2.1 \mathrm{~g}$ of fiber, $0.91 \mathrm{~g}$ of protein, $0.31 \mathrm{~g}$ of fat, $0.3 \mathrm{~g}$ of sugar, $6.31 \mathrm{~g}$ of carbohydrates, 26\% manganese, 3\% Vitamin C, 16\% iron, 5\% potassium. (Khan 2019) ${ }^{[14]}$. Ghee chemically may be defined as complex lipids of triacylglycerol, together with small quantity of free fatty acids, phospholipids, sterols, hydrocarbons, carbonyl compounds, fat soluble vitamins (A,D, E, and K), carotenoid pigments, moisture and traces of elements like copper and iron. Ghee is also good source of butyric acid, conjugated linoleic acid, phospholipid and fat-soluble vitamins A, D, E and K. etc. The present study was proposed to prepared ghee by using turmeric powder having medicinal and nutritional properties and examined its physico-chemical properties.

\section{Materials and Methodology}

In the present research work the standard material and methods were used and work was carried out at the Department of Animal Husbandry and Dairy Science, College of Agriculture Latur, Vasantrao Naik Marathwada Krishi Vidyapeeth, Parbhani.

\section{Physico-chemical properties of the product}

Physico-chemical parameters like moisture content, free fatty acid, butyro-refractometer reading, iodine value, peroxide value and melting point were examined by adopting standard procedure and data were analyzed statistically by using Completely Randomized Design (CRD) as per Panse and Sukhatme (1985) ${ }^{[21]}$. 


\section{Result and Discussion}

Moisture content of turmeric powder added ghee

The data on moisture content in ghee is presented in table 1. It was observed that the average moisture (per cent) of ghee prepared under each treatment was $\mathrm{T}_{1}(0.237), \mathrm{TM}_{2}(0.218)$, $\mathrm{TM}_{3}(0.206)$ and $\mathrm{TM}_{4}(0.195)$ per cent respectively in $1^{\text {st }}$ stage, in $2^{\text {nd }}$ stage $\mathrm{TD}_{2}(0.215), \mathrm{TD}_{3}(0.206)$ and $\mathrm{TD}_{4}(0.195)$ and in $3^{\text {rd }}$ stage $\mathrm{TB}_{2}(0.189), \mathrm{TB}_{3}(0.200)$ and $\mathrm{TB}_{4}(0.210)$. From the table 1 it is clear that the moisture content of the control $\left(\mathrm{T}_{1}\right)$ ghee was 0.237 per cent.

As the proportion of the turmeric powder level increased the moisture per cent of ghee decreased. The decreasing trend of moisture from $T_{2}$ to $T_{4}$ in $1^{\text {st }}$ and $2^{\text {nd }}$ stages may be due to the increased in level of turmeric powder level which expose more hydrophobic nature of turmeric as curcumin is hydrophobic in nature supported by Lodh and Khamrui (2017) ${ }^{[18]}$. But in third stage the moisture percent was found increased as the turmeric powder increased might be due to the less processing of turmeric occurred due to which the hydrophilic property of turmeric remain sustain or may be increased in combination of milk fatty acids in this case. As Yazadi (2012) ${ }^{[33]}$ stated that curcumin in is hydrophobic in nature and the processing affected on the structural and functional properties of food ingredients. (Fox and McSweeney, 1998) ${ }^{[9]}$.

Table 1: Moisture content in turmeric powder added ghee

\begin{tabular}{|c|c|c|c|c|c|}
\hline Treatments & \multicolumn{5}{|c|}{ Moisture per cent (\%) } \\
\hline & R-I & R-1I & R-III & R-IV & Mean \\
\hline $\mathrm{T}_{1}$ & 0.235 & 0.239 & 0.245 & 0.232 & 0.237 \\
\hline $\mathrm{TM}_{2}$ & 0.220 & 0.218 & 0.216 & 0.218 & 0.218 \\
\hline $\mathrm{TM}_{3}$ & 0.209 & 0.205 & 0.204 & 0.207 & 0.206 \\
\hline $\mathrm{TM}_{4}$ & 0.200 & 0.199 & 0.192 & 0.190 & 0.195 \\
\hline $\mathrm{TD}_{2}$ & 0.218 & 0.215 & 0.212 & 0.217 & 0.215 \\
\hline $\mathrm{TD}_{3}$ & 0.208 & 0.202 & 0.206 & 0.208 & 0.206 \\
\hline $\mathrm{TD}_{4}$ & 0.198 & 0.191 & 0.200 & 0.193 & 0.195 \\
\hline $\mathrm{TB}_{2}$ & 0.189 & 0.190 & 0.187 & 0.188 & 0.189 \\
\hline $\mathrm{TB}_{3}$ & 0.200 & 0.207 & 0.197 & 0.198 & 0.200 \\
\hline $\mathrm{TB}_{4}$ & 0.210 & 0.216 & 0.208 & 0.210 & 0.210 \\
\hline $\mathrm{SE}= \pm 0.00182 \mathrm{CD}$ at $5 \%=0.005267$ \\
\hline
\end{tabular}

The values recorded in moisture content in the present investigation were comparable with below mentioned research. PFA, (2008) [23] as per PFA standards moisture content of ghee should not be more than $0.5 \%$. Sserunjogi et al. (1998) ${ }^{[31]}$ the moisture content of ghee sample varies from $0.170 .19 \%$ among different treatments. Moisture content of ghee is reported to vary from $0.3 \%$ maximum. Gupta et al. (1979) ${ }^{[11]}$ reported that $2.5 \%$ to $5.0 \%$ moisture in ghee offered antioxidant properties. Achaya (1997) ${ }^{[2]}$ storage stability of ghee is attributed to the low moisture content $(0.2 \%)$. Buch et al. (2014) ${ }^{[5]}$ studied that moisture content in paneer decreased $50.40(0.4 \%)$ and $50.02(0.6 \%)$ with increase in level of turmeric powder in paneer. Paul et al. (2018) ${ }^{[21]}$ prepared paneer by incorporating herbal extract i.e. basil ginger and mint in which moisture content of ginger added paneer decreased $44.88\left(\mathrm{~T}_{1}\right) 52.45\left(\mathrm{~T}_{2}\right), 52.15\left(\mathrm{~T}_{3}\right)$ and $52.08\left(\mathrm{~T}_{4}\right)$. Prasad et al. (2017) ${ }^{[24]}$ prepared burfi using different herb in which moisture content of turmeric powder added burfi decreased than control 14.68 (control) and 14.38(1\%).
Free fatty acid content

The free fatty acid content in turmeric powder added ghee as influenced by different proportions of turmeric powder incorporated in buffalo milk has been presented in table. 2

Table 2: FFA content in turmeric powder added ghee (in per cent)

\begin{tabular}{|c|c|c|c|c|c|}
\hline Treatments & \multicolumn{5}{|c|}{ FFA (per cent) } \\
\hline & R-I & R-1I & R-III & R-IV & Mean \\
\hline $\mathrm{T}_{1}$ & 0.20 & 0.21 & 0.22 & 0.20 & 0.20 \\
\hline $\mathrm{TM}_{2}$ & 0.18 & 0.20 & 0.21 & 0.19 & 0.19 \\
\hline $\mathrm{TM}_{3}$ & 0.11 & 0.13 & 0.13 & 0.16 & 0.13 \\
\hline $\mathrm{TM}_{4}$ & 0.05 & 0.11 & 0.09 & 0.10 & 0.08 \\
\hline $\mathrm{TD}_{2}$ & 0.19 & 0.17 & 0.18 & 0.20 & 0.17 \\
\hline $\mathrm{TD}_{3}$ & 0.14 & 0.14 & 0.12 & 0.13 & 0.12 \\
\hline $\mathrm{TD}_{4}$ & 0.09 & 0.11 & 0.09 & 0.10 & 0.11 \\
\hline $\mathrm{TB}_{2}$ & 0.09 & 0.05 & 0.08 & 0.07 & 0.10 \\
\hline $\mathrm{TB}_{3}$ & 0.13 & 0.13 & 0.12 & 0.11 & 0.11 \\
\hline $\mathrm{TB}_{4}$ & 0.15 & 0.16 & 0.15 & 0.18 & 0.15 \\
\hline $\mathrm{SE}= \pm 0.01501 \mathrm{CD}$ at $5 \%=0.043348$ \\
\hline
\end{tabular}

The data on free fatty acid content in ghee is presented in table 2. It was observed that the average FFA content of ghee prepared under each treatment was $\mathrm{T}_{1}(0.20), \mathrm{TM}_{2}(0.19)$, $\mathrm{TM}_{3}(0.13)$ and $\mathrm{TM}_{4}(0.08)$ per cent respectively in $1^{\text {st }}$ stage, in $2^{\text {nd }}$ stage $\mathrm{TD}_{2}(0.17), \mathrm{TD}_{3}(0.12)$ and $\mathrm{TD}_{4}(0.11)$ and in $3^{\text {rd }}$ stage $\mathrm{TB}_{2}(0.10), \mathrm{TB}_{3}(0.11)$ and $\mathrm{TB}_{4}(0.15)$. The content of free fatty acid was found decreased as the proportion of turmeric increased indicate that the excess FFA in treated treatments absorb or link with hydrophobic part of turmeric may be curcumin, which showed stronger antioxidant activity in quenching free radicals, Lodh and Khamrui (2017) ${ }^{[18]}$. This changes in developed treatment may be helpful for enhancement of shelf life of ghee. As the FFA more prone for oxidative rancidity of ghee, might be reduce the possibility in developed treatments. As per the PFA, (2008) ${ }^{[23]}$ standards FFA content of ghee should not be more than 3\%.As per the standards and categories of ghee mentioned by AGMARK, according to agmark free fatty acid contains should not be more than $1.4 \%$ for special grade ghee, $2.50 \%$ for general grade ghee and $3.0 \%$ for standard grade ghee, the ghee of present study comes under special grade ghee.

Sharma (1981) ${ }^{[27]}$ reported the FFA content of ghee samples varied on an average 0.16 to $0.20 \%$ (unripened cream) among different treatments. FFA content of ghee is reported to vary from 0.23 to 0.28 .

Lodh and Khamuri (2016) ${ }^{[17]}$ reported initially there was no significant difference in FFA content among the different ghee samples. The initial FFA content of the CFB, CFP, BGB, BGP, CB and CP were 0.204 $\pm 0.011,0.200 \pm 0.006$, $0.200 \pm 0.006$, and $0.223 \pm 0.009 \%$.

Naaz and Prakash (2000) ${ }^{[20]}$ studied the traditional method of ghee production with various spices (cardamom, clove, fenugreek, pepper and turmeric) and determine the effect of these spices on keeping quality. FFA value were lowest with turmeric.

\section{Peroxide value}

The peroxide value in turmeric powder added ghee as influenced by different proportions of turmeric powder incorporated in buffalo milk has been presented in table 3 . 
Table 3: Peroxide value in turmeric powder added ghee

\begin{tabular}{|c|c|c|c|c|c|}
\hline \multirow[t]{2}{*}{ Treatments } & \multicolumn{5}{|c|}{ Peroxide value (meq $\mathrm{O}_{2} / \mathrm{kg}$ ) } \\
\hline & R-I & R-1I & R-III & R-IV & Mean \\
\hline $\mathrm{T}_{1}$ & 0.30 & 0.32 & 0.31 & 0.31 & 0.31 \\
\hline $\mathrm{TM}_{2}$ & 0.30 & 0.31 & 0.31 & 0.30 & 0.30 \\
\hline $\mathrm{TM}_{3}$ & 0.29 & 0.30 & 0.29 & 0.30 & 0.29 \\
\hline $\mathrm{TM}_{4}$ & 0.28 & 0.28 & 0.27 & 0.28 & 0.27 \\
\hline $\mathrm{TD}_{2}$ & 0.32 & 0.31 & 0.30 & 0.32 & 0.31 \\
\hline $\mathrm{TD}_{3}$ & 0.31 & 0.30 & 0.29 & 0.30 & 0.30 \\
\hline $\mathrm{TD}_{4}$ & 0.29 & 0.28 & 0.27 & 0.29 & 0.28 \\
\hline $\mathrm{TB}_{2}$ & 0.28 & 0.29 & 0.28 & 0.28 & 0.28 \\
\hline $\mathrm{TB}_{3}$ & 0.29 & 0.31 & 0.29 & 0.29 & 0.29 \\
\hline $\mathrm{TB}_{4}$ & 0.30 & 0.32 & 0.32 & 0.31 & 0.31 \\
\hline
\end{tabular}

The peroxide value of turmeric powder added ghee of the treatment $\mathrm{T}_{1}, \mathrm{TM}_{2}, \mathrm{TM}_{3}$ and $\mathrm{TM}_{4}$ in $1^{\text {st }}$ stage were found to be as $0.31,0.30,0.29$ and 0.27 per cent, respectively. $\mathrm{TD}_{2}, \mathrm{TD}_{3}$ and $\mathrm{TD}_{4}$ in $2^{\text {nd }}$ stage were $0.31,0.30,0.28$ and $\mathrm{TB}_{2}, \mathrm{~TB}_{3}$ and $\mathrm{TB}_{4}$ in $3^{\text {rd }}$ stage as $0.28,0.29$ and 0.31 , respectively. It is clear from above table that the peroxide value of turmeric powder added ghee was positive in first and second stage of addition but observed negative in case of third stage of addition, indicate that the stage of addition of turmeric in food most important to preserve its functionality as well as nutritionally. Mehulkumar and Aparnathi (2011) ${ }^{[19]}$ reported that the addition of curcumin powder at $0.4 \%$ gave ghee lower peroxide value as compare to control sample. $1^{\text {st }}$ day of storage in control ghee 0.32 and in turmeric added ghee is 0.32 . $3^{\text {rd }}$ day of storage ghee 1.75 and turmeric added ghee is 1.55 .

Ghatak and Bandyopadhyay (1989) [10] reported peroxide value of 0.2 to 0.7 and 0.6 to $3.10\left(\mathrm{mM}\right.$ of $\mathrm{O}_{2} / \mathrm{kg}$ ) for ghee sample from organized and unorganized sector respectively. The age of samples at the time of analysis was in the range of 1 to 4 months.

Hazra et al. (2015) ${ }^{[12]}$ reported that addition of two variety of tomato skin increase the oxidative stability of ghee during accelerated storage. Peroxide value was lower for tomato added ghee sample as compare to control sample.

Naaz and Prakash (2000) ${ }^{[20]}$ studied the traditional method of ghee production with various spices (cardamom, clove, fenugreek, pepper and turmeric) and determine the effect of these spices on keeping quality. Peroxide value $1.39 \mathrm{meq} / \mathrm{kg}$ were lowest with turmeric.

Fasludeen (2016) ${ }^{[8]}$ peroxide value was less in pomegranate peel powder 0.908 .

Lodh and Khamurai (2016) ${ }^{[17]}$ prepared curcumin fortified buffalo ghee in that the initial value of control ghee after 3 day of storage $(<0.005)$. At the end of the six day of storage peroxide value of curcumin fortified buffalo ghee curcumin fortified buffalo ghee (CFB), curcumin fortified buffalo ghee in PE (polyethelene) pouch (CFP), control buffalo ghee in HDPE (high density polyethelene) bottle (CB) and control buffalo ghee in $\mathrm{PE}$ pouch $(\mathrm{CP})$ sample were $0.556 \pm 0.002$, $0.543 \pm 0.001, \quad 3.859 \pm 0.002$ and $3.730 \pm 0.003$ meq. $\mathrm{o}_{2} / \mathrm{kg}$ respectively.

Singh et al. (2014) ${ }^{[30]}$ reported the peroxide values of the paneer varies from 0.486 to 2.38 which shows that the peroxide value increased gradually during the storage.

\section{Butyro-refractometer reading}

The Butyro-refractometer reading in turmeric powder added ghee as influenced by different proportions of turmeric powder incorporated in buffalo milk has been presented in table 4.

Table 4: Butyro-refractometer reading in turmeric powder added ghee

\begin{tabular}{|c|c|c|c|c|c|}
\hline Treatments & \multicolumn{5}{|c|}{ Butyro-refractometer reading } \\
\hline & R-I & R-1I & R-III & R-IV & Mean \\
\hline $\mathrm{T}_{1}$ & 41.60 & 41.61 & 41.52 & 41.50 & 41.55 \\
\hline $\mathrm{TM}_{2}$ & 40.40 & 40.40 & 40.39 & 40.37 & 40.39 \\
\hline $\mathrm{TM}_{3}$ & 40.22 & 40.26 & 40.21 & 40.27 & 40.24 \\
\hline $\mathrm{TM}_{4}$ & 40.09 & 40.12 & 40.10 & 40.14 & 40.11 \\
\hline $\mathrm{TD}_{2}$ & 40.42 & 40.43 & 40.41 & 40.39 & 40.41 \\
\hline $\mathrm{TD}_{3}$ & 40.25 & 40.25 & 40.26 & 40.21 & 40.24 \\
\hline $\mathrm{TD}_{4}$ & 40.08 & 40.09 & 40.15 & 40.17 & 40.12 \\
\hline $\mathrm{TB}_{2}$ & 40.56 & 40.54 & 40.59 & 40.57 & 40.56 \\
\hline $\mathrm{TB}_{3}$ & 40.68 & 40.71 & 40.70 & 40.69 & 40.69 \\
\hline $\mathrm{TB}_{4}$ & 40.83 & 40.84 & 40.88 & 40.80 & 40.83 \\
\hline $\mathrm{SE}= \pm 0.01507 \mathrm{CD}$ at 5\% & $\mathbf{6} 0.043523$ \\
\hline
\end{tabular}

The butyro-refractometer reading of turmeric powder added ghee of the treatment $\mathrm{T}_{1}, \mathrm{TM}_{2}, \mathrm{TM}_{3}$ and $\mathrm{TM}_{4}$ in $1^{\text {st }}$ stage were found to be as $41.55,40.39,40.24$ and 40.11 per cent, respectively. $\mathrm{TD}_{2}, \mathrm{TD}_{3}$ and $\mathrm{TD}_{4}$ in $2^{\text {nd }}$ stage as $40.41,40.24$ and 40.12 and in $3^{\text {rd }}$ stage $\mathrm{TB}_{2}, \mathrm{~TB}_{3}$ and $\mathrm{TB}_{4}$ were 40.56 , 40.69 and 40.83 , respectively. It is observed from the butyrorefractometer reading of turmeric powder added ghee samples that turmeric powder reduced the butyro-refractometer reading of treated samples than control might be due to the scattering and reflecting difference of turmeric components than control ghee changed butyro-refractometer reading of treated samples. The present values for BR reading were found within a limit of standards prescribed by PFA, (2008) ${ }^{[23]}$ standards BR reading of ghee should be 40.0 to 43.5 and Agmark standards BR reading of ghee should be 40.0 to 43.0 for areas other than cotton tract areas in Gujarat. The findings also supported by following workers:

Mehulkumar and Aparnathi (2011) ${ }^{[19]}$ reported the curcumin fortified buffalo ghee butyro-refractometer reading at $40^{\circ} \mathrm{C}$ in control ghee 41.7, butylated hydroxyanisole (BHA) added ghee is 40.4 and in turmeric $(0.5 \%)$ added ghee is 40.2 . Kapadiya (2017) ${ }^{[13]}$ reported the BR reading of different ghee samples at $40^{\circ} \mathrm{C}$ varied on an average from 40.61 to 42.16 . All the sample of ghee treated with both the sample like betel leaves (41.05) and blend of betel leaves plus liquorice (40.61) showed the significant lower BR reading compare to BR reading of control ghee.

Achaya (1948) ${ }^{[3]}$ the BR reading of ghee samples at $40^{\circ} \mathrm{C}$ varied on an average from 40.2 to 41.7 among different treatments. BR reading of ghee is reported to vary from 39.2 to 43.1 . 
Lodh and Khamurai (2016) ${ }^{[17]}$ reported butyro-refractometer reading at $40^{\circ} \mathrm{C}$ in curcumin fortified buffalo ghee is $41.5 \pm$ 0.01 .

Ramya et al. (2019) ${ }^{[25]}$ reported average value of BR reading at $40^{\circ} \mathrm{C}$ in uthkulighee is $40.7 \pm 0.04$.

\section{Iodine value}

The iodine value in turmeric powder added ghee as influenced by different proportions of turmeric powder incorporated in buffalo milk has been presented in table 5 .

The iodine value of turmeric powder added ghee of the treatment $\mathrm{T}_{1}, \mathrm{TM}_{2}, \mathrm{TM}_{3}$ and $\mathrm{TM}_{4}$ in $1^{\text {st }}$ stage were found to be as $31.14,31.27,31.35$ and 31.44 respectively. $\mathrm{TD}_{2}, \mathrm{TD}_{3}$ and $\mathrm{TD}_{4}$ in $2^{\text {nd }}$ stage $31.22,31.43,31.47$ and in $3^{\text {rd }}$ stage 31.32 , 31.25 and 31.19, respectively for $\mathrm{TB}_{2}, \mathrm{~TB}_{3}$ and $\mathrm{TB}_{4}$. The pattern for iodine value of turmeric powder added ghee samples were not show fixed trend it was found decreasing in $1^{\text {st }}$ and $2^{\text {nd }}$ stage whereas increasing in $3^{\text {rd }}$ stage of addition of turmeric powder.

Table 5: Iodine value in turmeric powder added ghee

\begin{tabular}{|c|c|c|c|c|c|}
\hline Treatments & \multicolumn{5}{|c|}{ Iodine value (gm) } \\
\hline & R-I & R-1I & R-III & R-IV & Mean \\
\hline $\mathrm{T}_{1}$ & 31.12 & 31.16 & 31.15 & 31.13 & 31.14 \\
\hline $\mathrm{TM}_{2}$ & 31.29 & 31.22 & 31.28 & 31.29 & 31.27 \\
\hline $\mathrm{TM}_{3}$ & 31.35 & 31.36 & 31.32 & 31.37 & 31.35 \\
\hline $\mathrm{TM}_{4}$ & 31.43 & 31.40 & 31.48 & 31.46 & 31.44 \\
\hline $\mathrm{TD}_{2}$ & 31.21 & 31.20 & 31.25 & 31.24 & 31.22 \\
\hline $\mathrm{TD}_{3}$ & 31.34 & 31.31 & 31.38 & 31.35 & 31.34 \\
\hline $\mathrm{TD}_{4}$ & 31.48 & 31.48 & 31.49 & 31.45 & 31.47 \\
\hline $\mathrm{TB}_{2}$ & 31.32 & 31.31 & 31.34 & 31.33 & 31.32 \\
\hline $\mathrm{TB}_{3}$ & 31.25 & 31.27 & 31.26 & 31.23 & 31.25 \\
\hline $\mathrm{TB}_{4}$ & 31.18 & 31.20 & 31.20 & 31.19 & 31.19 \\
\hline $\mathrm{SE}= \pm 0.01163 \mathrm{CD}$ at $5 \%=0.033584$ \\
\hline
\end{tabular}

Deshmukh (2018) ${ }^{[7]}$ reported that the iodine value was small increased with herb extract. Iodine value of control ghee is 35.33 and ashwagandha herb added is 35.48 . Lakshminarayana and Murthy (1985) ${ }^{[16]}$ reported the average iodine value of buffalo ghee is 31.1.Ramya et al. (2019) [25] reported that the average iodine value of Uthukuli buffalo ghee samples were $27.1 \pm 0.74$.

\section{Melting point}

The melting point in turmeric powder added ghee as influenced by different proportions of turmeric powder incorporated in buffalo milk has been presented in table 6 .

Table 6: Melting point in turmeric powder added ghee

\begin{tabular}{|c|c|c|c|c|c|}
\hline Treatments & \multicolumn{5}{|c|}{ Melting point $\left({ }^{\circ} \mathrm{C}\right)$} \\
\hline & R-I & R-1I & R-III & R-IV & Mean \\
\hline $\mathrm{T}_{1}$ & $32.26^{\circ} \mathrm{C}$ & $32.28^{\circ} \mathrm{C}$ & $32.27^{\circ} \mathrm{C}$ & $32.26^{\circ} \mathrm{C}$ & 32.26 \\
\hline $\mathrm{TM}_{2}$ & $32.31^{\circ} \mathrm{C}$ & $32.33^{\circ} \mathrm{C}$ & $32.32^{\circ} \mathrm{C}$ & $32.34^{\circ} \mathrm{C}$ & 32.32 \\
\hline $\mathrm{TM}_{3}$ & $32.33^{\circ} \mathrm{C}$ & $32.32^{\circ} \mathrm{C}$ & $32.33^{\circ} \mathrm{C}$ & $32.34^{\circ} \mathrm{C}$ & 32.33 \\
\hline $\mathrm{TM}_{4}$ & $32.34{ }^{\circ} \mathrm{C}$ & $32.34^{\circ} \mathrm{C}$ & $32.34{ }^{\circ} \mathrm{C}$ & $32.34{ }^{\circ} \mathrm{C}$ & 32.34 \\
\hline $\mathrm{TD}_{2}$ & $32.29^{\circ} \mathrm{C}$ & $32.28^{\circ} \mathrm{C}$ & $32.30^{\circ} \mathrm{C}$ & $32.29^{\circ} \mathrm{C}$ & 32.29 \\
\hline $\mathrm{TD}_{3}$ & $32.34^{\circ} \mathrm{C}$ & $32.32^{\circ} \mathrm{C}$ & $32.30^{\circ} \mathrm{C}$ & $32.27^{\circ} \mathrm{C}$ & 32.30 \\
\hline $\mathrm{TD}_{4}$ & $32.31^{\circ} \mathrm{C}$ & $32.33^{\circ} \mathrm{C}$ & $32.33^{\circ} \mathrm{C}$ & $32.32^{\circ} \mathrm{C}$ & 32.32 \\
\hline $\mathrm{TB}_{2}$ & $32.40^{\circ} \mathrm{C}$ & $32.34^{\circ} \mathrm{C}$ & $32.36^{\circ} \mathrm{C}$ & $32.35^{\circ} \mathrm{C}$ & 32.36 \\
\hline $\mathrm{TB}_{3}$ & $32.37^{\circ} \mathrm{C}$ & $32.37^{\circ} \mathrm{C}$ & $32.39^{\circ} \mathrm{C}$ & $32.48^{\circ} \mathrm{C}$ & 32.39 \\
\hline $\mathrm{TB}_{4}$ & $32.46^{\circ} \mathrm{C}$ & $32.44^{\circ} \mathrm{C}$ & $32.43^{\circ} \mathrm{C}$ & $32.43^{\circ} \mathrm{C}$ & 32.44 \\
\hline
\end{tabular}

The melting point of turmeric powder added ghee of the treatment $\mathrm{T}_{1}, \mathrm{TM}_{2}, \mathrm{TM}_{3}$ and $\mathrm{TM}_{4}$ in $1^{\text {st }}$ stage were found to be as $32.26,32.32,32.33$ and 32.34 respectively. $\mathrm{TD}_{2}, \mathrm{TD}_{3}$ and $\mathrm{TD}_{4}$ in $2^{\text {nd }}$ stage $32.29,32.30,32.32$ and in $3^{\text {rd }}$ stage 32.36 , 32.39 and 32.44 for $\mathrm{TB}_{2}, \mathrm{~TB}_{3}$ and $\mathrm{TB}_{4}$, respectively. The melting point of turmeric powder added ghee samples were found increased as the turmeric powder increased in the ghee samples might be due to the decreased in FFA in successive treatments of turmeric powder added samples which have liquid or less melting temperature responsible for lowering melting point of developed samples supported by Fox and McSweeney, 1998 [9] in his book on, "Advanced Dairy Chemistry" volume second on Lipids and following researcher in their respective milk products developed by using turmeric.

Kumar et al., (2015) ${ }^{[15]}$ reported that nanoencapsulated curcumin ice-cream melts slower $(0.83 \pm 0.01 \mathrm{~g} / \mathrm{min})$ than the control ice-cream $(0.90 \pm 0.08)$. Arun Raj et al. (2016) ${ }^{[4]}$ reported melting point of ashwagandhaghritha is $43^{\circ} \mathrm{C}$. Ramya et al. (2019) [25] reported melting point of the prepared uthukuli buffalo ghee was $33.5 \pm 0.61$.
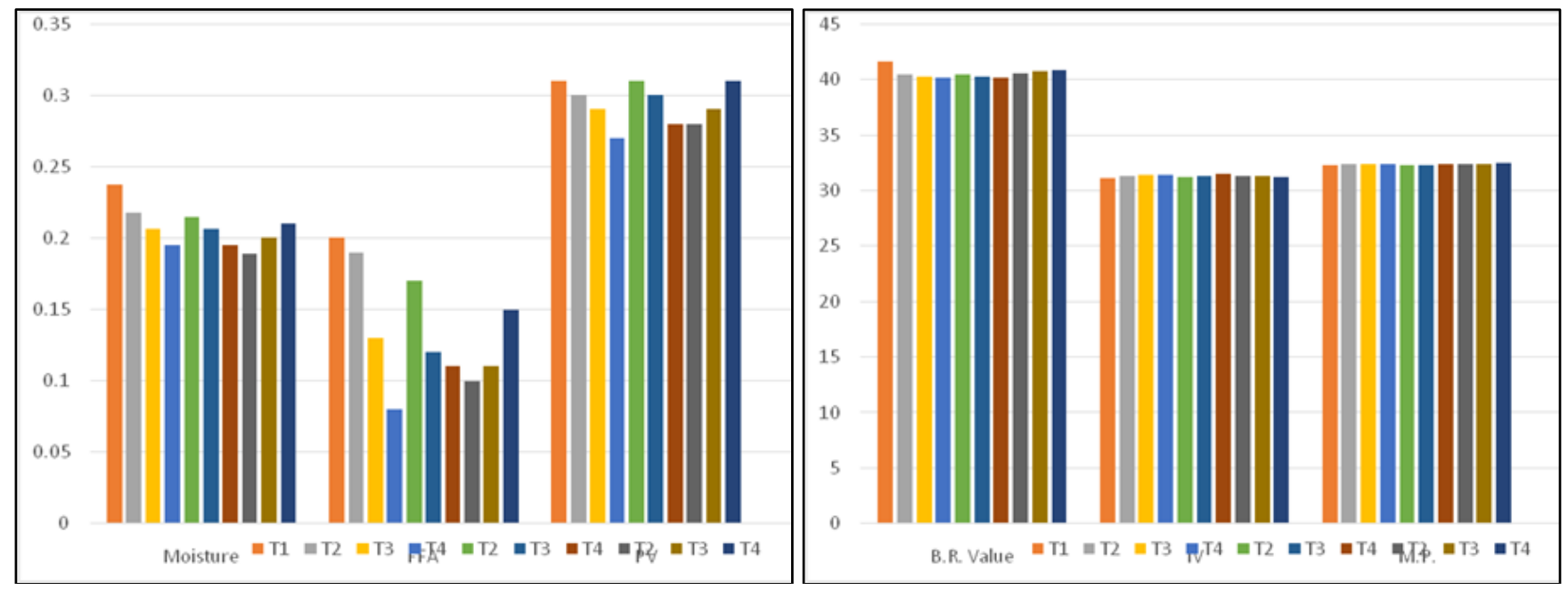

Fig 1: Physico-chemical Properties of Turmeric Powder added Ghee

\section{Conclusion}

Use of herbs as ayurvedic medicines is a traditional practice in India. Turmeric is a medicinal plant having various health benefits without any side effects. Ghee could absorb all the fat soluble and partially water soluble components from the herbs enhancing their effectiveness. Therefore, it is used as a base material for the preparation of many ayurvedic medicines. The turmeric powder of $0.5 \%, 1 \%$ and $1.5 \%$ was added in all 
three stages. $0.5 \%$ is more acceptable than $1.5 \%$ added turmeric powder in ghee. It was observed that as the amount of turmeric powder increased, there was increase in iodine value, melting point whereas, decreasemoisture content, peroxide value, butyro-refractometer reading, free fatty acidof ghee.

\section{References}

1. AGMARK. Ghee Grading and Marking Rules, 1938 (as amended in 1988). Ministry of Food and Agriculture, Department of Agriculture, Government of India, New Delhi 1988.

2. Achaya KT. Ghee, Vanaspati and Special fats in India. Lipid Technologies and Applications. Gunstone F. D., Pandley F. B. and Marcel Dekkar Inc., New York 1997, Pp: 369-390.

3. Achaya KT. Rancidity in Indian Butterfats (ghee). Biochem 1948;44:561.

4. Arun Raj, Viswaroopan D, Uppinakudru S. Standardization of AshwagandhaGhrita: a Herbal Ghee based Ayurvedic Medicinal preparation. International Journal of Pharmaceutical Sciences and Research 2016;7(2):819-823.

5. Buch S, Pinto S, Aparanti K. Evaluation of Efficacy of Turmeric as a Preservative in Paneer. J Food Sci. Technol 2014.

6. Craig WJ. Health Promoting properties of common Herbs. Am. J Cli. Nutr 1999;70:491-499.

7. Deshmukh AR, Desale RJ, Fulpagare YG, Khupse SM. Physico-Chemical study of herbal Ghee prepared with Ethanolic Extract of Asparagus racemosus (Shatavari) and Withaniasomnifera (Ashwagandha). International Journal of Current Microbiology and Applied Sciences 2018;7(8):257-265.

8. Fasludeen NS. Comparison of the Antioxidants potential of Natural Antioxidants in Ghee. International Journal of Multidisciplinary and Current Research 2016;4:432-434.

9. Fox PF, McSweeney PLH. Dairy Chemistry and Biochemistry. Department of Food Chemistry University College Cork, Ireland 1998.

10. Ghatak PK, Bandyopadhyay AK. Chemical and Sensory quality of Ghee marketed in Calcultta and Kalyani (West Bengal) Indian Dairyman 1989;41:515-518.

11. Gupta S, Sukhija PS, Bhatis IS. Role of Phenolics and Phospholipids as antioxidants. Milchwissenschaft 1979;34:205.

12. Hazra T, Mehta BM, Aparnathi KD. Effect of Two Varieties of Tomato skin addition on Oxidative stability of Ghee. A Comparative Study International Journal of Food and Nutritional Sciences 2015;3(3):24-27.

13. Kapadiya DB, Aparnathi KD. Comparison of Physicochemical, Nutritional and Sensory aspect of Ghee obtained from different Species. International Journal of Trend in Scientific Research and Development 2017;1(6):1231-1236.

14. Khan N. Miracles of the Golden Spice-Turmeric. SM Dermatology Journal 2019;5(1):1031.

15. Kumar R, Sari P, Mann B, Singh R, Sharma R, Bhardwaj $\mathrm{M}$, et al. Preparation and Characterization of Nanoemulsion Encapsulating Curcumin. Food Hydrocolloids 2015;43:540-546.

16. Lakssminarayanan M, Murthy R. Cow and Buffalo milk fat fractions. Part-1-yield, fatty acid composition and Physico-chemical characteristics of the fractions. Indian Journal of Dairy Science 1985;38:256-264.
17. Lodh J, Khamuri K. Development of Technology for Curcumin Fortified Buffalo Ghee and evaluation of its functional attributes. M. Tech Thesis submitted to National Dairy Institute (Deemed University) Karnal 2016.

18. Lodh J, Khamrai K. Evaluation of Physico-Chemical Changes in Curcumin Fortified Buffalo Ghee during storage at $30 \pm 1^{\circ} \mathrm{C}$. International Journal of Chemical Studies 2017;5(2):141-144.

19. Mehulkumar S, Aparnathi KD. Antioxidant activity of Turmeric in Ghee. M.Sc Thesis submitted to Anand Agriculture University, Anand, Gujrat 2011.

20. Naaz T, Prakash J. Storage Stability of Ghee with added Spices. Indian Journal of Nutrition and Dieteticsm 2000;37(1):20-27.

21. Panse VG, Sukhatme PV. Statistical Methods for Agricultural Workers. Second Edn. ICAR, New Delhi 1985.

22. Paul V, Kushwaha P, Paul A. Enrichment of low fat paneer by incorporating herbal extracts (Basil, Ginger and Mint). Nutrition and Public Health, Sam Higginbottom University of Agriculture, Technology and Sciences, Allahabad, Uttar Pradesh, India. The Pharma Innovation Journal 2018;7(7):472-476.

23. PFA. Prevention of Food Adulteration Act (1954) and Rules (1955). Seventh amendment. The universal law publishing Co. Pvt. Ltd 2008, PP:102.

24. Prasad W. Studied on Technology and Shelf life of Herb incorporated Burfi. Thesis submitted to Karnal-132 001 (Hariyana), India 2017.

25. Ramya SB, Baskaran D, Vijayarani K, Palanidorai R, Ramasamy D. A study on Physico-Chemical properties of UthukuliGhee. International Journal of Current Microbiology and Applied Sciences 2019;8(4):20902099.

26. Samah SM, Youssef AM. Potential Application of Herbs and Spices and Their Effects in Functional Dairy Products. Dokki, Gizza, Egypt. Heliyon 2019.

27. Sharma RS. Ghee: A resume of recent research. Journal of food science and technology 1981;18:Pp:70.

28. Shishodia S, Sethi G, Aggarwal BB. Curcumin: Getting back to the roots. Ann. N. Y Acad. Sci. 2005;1056:206217.

29. Singh BP, Panesar S, Nanda V. Utilization of carrot pomace for the preparation of a value added product. World J. Dairy Food Sci 2006;1(1):22-27.

30. Singh RR, Singh R, Shakya BR. Impact of Turmeric addition on the Properties of prepared from different types of milk. International Journal of Current Engineering and Technology 2014;4(3):1874-1883.

31. Sserunjogiab M, Abrahamsena R, Narvhusa J. A review paper: Current Knowledge of Ghee and related products. Int. Dairy Journal 1998;8:677-688.

32. Taher M, Hamidon H, Susanti D, Zakaria ZA. Garcinia atroviridis-a review on phytochemicals and pharmacological properties. Marmara Pharm J 2017;21(1):38-47.

33. Yazdi SR. Heating of milk alters the binding of Curcumin to casein Micelles. A Fluorescence Spectroscopy Study. Department of food Science, University of Guelph Ontario, Canada 2012;132(3):11431149. 